\title{
PERHITUNGAN ZAKAT HASIL PERTANIAN BAGI PETANI DI DESA KERUMUT LOMBOK TIMUR
}

\author{
Muaidy Yasin ${ }^{1}$, Surati², Akhmad Jufri ${ }^{3}$, L. Edy Herman Mulyono ${ }^{4}$ \\ Jurusan Ilmu Ekonomi dan Studi Pembangunan - Universitas Mataram \\ Muaidyyasin@unram.acid
}

\begin{abstract}
ABSTRAK
Pengabdian pada masyarakat ini berjudul "Penyuluhan Tentang perhitungan zakat hasil pertanian di Desa Kerumut Kecamatan Pringgabaya Lombok Timur", bertujuan untuk Memberikan pemahaman tentang zakat hasil pertanian kepada petani padi dan menjelaskan cara perhitungan besarnya zakat hasil pertanian.

Metode yang digunakan dalam kegiatan ini adalah metode metode ceramah dan diskusi kelompok terarah (focus discussion group) serta pendampingan kepada para peserta, dengan memberikan contoh dan cara perhitungan zakat hasil pertanian dan peternakan kepada para petani yang menajadi sasaran dalam kegiatan penyuluhan ini. Dari hasil diskusi kelompok terarah dengan peserta diperoleh informasi bahwa, para petani di desa kerumut pada umumnya telah mengeluarkan zakat hasil pertaniannya setelah panen usai dilakukan. Dalam penyaluran zakat hasil pertanian tersebut, para petani langsung memberikan zakat tersebut kepada warga di desa kerumut yang dianggap berhak menerimanya yaitu anggota masyarakat yang kurang mampu.

Pengelolaan zakat belum berjalan secara efektif, dibawah Badan Amil Zakat Desa (BAZDES). Badan ini dihajatkan untuk mengelola zakat yaitu menghimpun dan menyalurkan zakat baik zakat harta, zakat hasil pertanian maupun peternakan dan jenis zakat lainnya, namun hingga saat ini berlum berjalan sebagaimana diharapkan. Untuk lebih efektipnya pengelolaan zakat, maka perlu dilakukan reorgnisasi pengelolaan zakat yang ada sekarang ini, tidak lagi dibawah koordinasi Ketua Badan Amil Zakat Desa (Bazdes) tetapi dibawah Ta'mir Masjid.
\end{abstract}

Keyword: Perhitungan Zakat, Hasil pertanian, Petani

\begin{abstract}
This community service is entitled "Counseling on the calculation of zakat on agricultural products in Kerumut Village, Pringgabaya District, East Lombok", aims to provide an understanding of agricultural zakat to rice farmers and explain how to calculate the amount of zakat on agricultural products
\end{abstract}


The method used in this activity is the lecture method and focus group discussions as well as assistance to the participants, by providing examples and methods of calculating zakat on agricultural and livestock products to farmers who are the targets of this outreach activity. From the results of focus group discussions with participants, information was obtained that farmers in the village of Kerumut in general have issued zakat on their agricultural products after the harvest has been carried out. In the distribution of zakat on agricultural products, the farmers directly give the zakat to residents in the village of Kerumut who are considered entitled to receive it, namely members of the community who are underprivileged

Zakat management has not run effectively, under the Village Amil Zakat Agency (BAZDES). The purpose of this agency is to manage zakat, namely to collect and distribute zakat, both zakat on assets, zakat on agricultural and livestock products and other types of zakat, but so far this has not worked as expected. For a more effective zakat management, it is necessary to reorganize the current zakat management, no longer under the coordination of the Head of the Village Amil Zakat Agency (Bazdes) but under the Ta'mir Masjid.

Keywords: Calculation of Zakat, Agricultural Products, Farmers

\section{PENDAHULUAN}

Kabupaten Lombok Timur merupakan satu dari empat Kabupaten di Nusa Tenggara Barat termasuk dalam kategori daerah produksi padi sekaligus daerah sebagai penyangga pangan bagi masyarakat di Nusa tenggara Barat. Tiga dari empat daerah produksi tersebut meliputi Kabupaten Lombok Tengah, Kabupaten Sumbawa dan Kabupaten Bima. Upaya pemerintah dalam meningkatkan produksi padi di Nusa Tenggara Barat seiring dengan kebijakan umum pemerintah melalui gerakan peningkatan produksi beras nasional (P2BN), yang dicanangkan sejak tahun 2007 hingga sekarang.

Program ini dimaksudkan untuk meningkatkan prodiktivitas padi, perluasan areal tanam dan panen, pengamanan produksi dan penguatan kelembagaan dan permodalan. Dengan adanya program peningkatan produksi beras nasional (P2BN), terjadi kenaikan produktivitas dari rata-rata 43,2 kwintal per hektar menjadi 48,7 kuintal per hektar atau rata-rata sebesar 1,34 persen selama priode tahun 1999-2008, BPS (2019). Peningkatan ini disebabkan oleh makin berkembangnya penggunaan teknologi pertanian yang digunakan, penggunaan 


\section{Jurnal ABDIMAS INDEPENDEN}

Vol. 2, No. 1, Mei 2021

benih padi unggul dan peningkatan kesadaran petani akan pentingnya penanganan pasca panen.

Selain terjadi peningkatan produktivitas lahan persatuan luas (per hektar), juga terjadi peningkatan produksi dalam kurun waktu yang sama yaitu rata-rata 2,55 persen per tahun. Peningkatan produksi ini sebagai akibat dari gencarnya pemerintah melaksanakan program P2BN dengan memberikan bantuan benih dan pupuk kepada petani sehingga produksi padi meningkat secara signifikan.

Kecamatan Pringgabaya yang memiliki luas wilayah $136,20 \mathrm{~km} 2$ yang terbagi dalam 15 Desa, salah satu diantaranya adalah Desa Kerumut yang wilayahnya berbatasan dengan Desa Teko disebelah utara, Desa Pohgading disebelah Timur, Desa Anggaraksa di sebelah selatan dan Desa Pohgading Timur di sebelah Timur. Luas Wilayah Desa Kerumut tidak begitu luas hanya 2,5 persen dari luas Kecamatan Pringgabaya. Kendati demikian, desa ini memiliki lahan pertanian dan perkebunan yang subur dengan tiga kali musim tanam dalam satu tahun.

Luas lahan sawah di Kecamatan Pringgabaya adalah 2.397 Ha yang terdiri atas lahan sawah irigasi teknis seluas $1.214 \mathrm{Ha}$, lahan setengah tehnis dan sederhana seluas 646 Ha dan irigasi sederhana Non PU seluas 537 Ha. Sedangkan Iahan Bukan sawah seluas $862 \mathrm{Ha}$ terdiri atas Kebun seluar 6,624 Ha, hutan negara seluas $1.997 \mathrm{Ha}$ dan lahan pekarangan $558 \mathrm{Ha}$. Dengan potensi lahan pertanian sebagaimana dipaparkan tersebut, produksi padi yang dihasilkan di kecamatan Pringgabaya sebanyak 26.554 Ton dengan luas panen $4.874 \mathrm{Ha}$. Jadi rata-rata produksi padi per hektanya adalah sebanyak $53.40 \mathrm{Kw}$ atau 5,34 ton per Hekter sawah. (Kacamatan Pringabaya Dalam Angka : 2019)

Adanya peningkatan produksi padi yang dihasilkan oleh petani, membawa konsekwensi logis kepada petani untuk mengeluarkan kewajiban membayar zakat atas hasil hasil pertaniannya. Kewajiban membayar zakat atas harta yang dimiliki sesuai dengan apa yang tertera dalam Surat At-Taubah ayat 103yang artinya Ambillah zakat dari sebagian harta mereka, dengan zakat itu kamu membersihkan dan mensucikan mereka dan berdo'alah untuk mereka. Sesungguhnya do'a kamu 
itu (menjadi) ketenteraman jiwa bagi mereka. Dan Allah Maha mendengar lagi Maha mengetahui. (QS. At-Taubah : 103).

Zakat adalah bagian dari harta yang wajib diberikan oleh setiap muslim yang memenuhi syarat kepada orang-orang tertentu, dengan syarat-syarat tertentu pula. Syarat-syarat yang dimaksudkan adalah nishab, haul dan kadarnya. (Muslihun Muslim, 2005: 76). Penelitian tentang Zakat telah banyak dilakukan oleh para peneliti dan pemerhati zakat dilhat dari berbagai sudut pandang. Mustikorini (2009) meneliti tentang potensi zakat sebagai alternatif untuk dana pembangunan masyarakat, dimana terdapat kesenjangan antara potensi dengan realisasi zakat. Yasin (2011) menyatakan bahwa penentuan besarnya zakat hasil pertanian oleh petani disamakan dengan besarnya zakat harta, sehingga dengan demikian pemahaman tentang zakat hasil pertanian oleh petani disamakan dengan besarnya zakat harta.

Perda No 9 Tahun 2002 Tentang Pengelolaan Zakat di Kabupaten Lombok Timur disebutkan bahwa zakat dapat menjadi sumber dana yang dapat dimanfaatkan bagi kesejahteraan masyarakat terutama untuk mengentaskan masyarakat dari kemiskinan dan menghilangkan kesenjangan sosial, sehingga perlu adanya pengelolaan zakat secara profesional dan bertanggung jawab oleh masyarakat dan pemerintah, dalam hal ini pemerintah berkewajiban memberikan perlindungan, pembinaan dan pelayanan kepada muzakki, mustahiq dan pengelola zakat.

Pengelolaan zakat Oleh pemerintah dengan membentuk sebuah lembaga pengelolaan zakat seperti LAZ dari daerah Tingkat Kabupaten hingga di Desa akan diperoleh keuntungan baik secara materiil yaitu lebih efektif dan efisien, mampu secara moriil yaitu terpeliharanya harkat dan martabat para penerima zakat itu sendiri. Dalam Al-Qur'an Surat Adz-Dzariyat ayat 19 yang artinya :

Dan pada harta-harta mereka ada hak untuk orang miskin yang meminta dan orang miskin yang tidak mendapat bagian (orang miskin yang tidak memintaminta) (QS. Adz-Dzariyat : 19). Hal ini mengharuskan intervensi pemerintah untuk 


\section{Jurnal ABDIMAS INDEPENDEN}

Vol. 2, No. 1, Mei 2021

mengambil sebagian dari harta mereka yang merupakan hak orang miskin tersebut melalui badan atau lembaga amil zakat.

\section{Perumusan Masalah}

Berangakat dari latarbelakang yang telah dipaparkan tersebut, dapat angkat permasalahan dalam pengabdian ini yaitu :

1. Sejauh mana pemahaman petani padi terhadap zakat hasil pertanian.

2' Bagaimana cara petani padi menghitung dan menentukan besarnya zakat hasil pertanian yang di peroleh dan bagaimana menyalurkannya kepada yang berhak menerimanya.

\section{Tujuan dan Manfaat}

a. Tujuan Kegiatan

Tujuan kegiatan ini adalah untuk :

a. Memberikan pemahaman tentang zakat hasil pertanian kepada petani.

b. Menjelaskan cara perhitungan besarnya zakat hasil pertanian dan bagaimana menyalurkannya kepada yang berhak menerimanya.

b. Manfaat Kegiatan

Manfaat dari kegiatan ini adalah :

a. Para petani dapat memahami tentang besarnya zakat pertanian .

b. Petani dapat menghitung besarnya zakat hasil pertanian sehingga kewajiban membayar zakat dapat dipenuhi sesuai dengan ketentuan syari,ah.

\section{METODE KEGIATAN}

Para petani di Desa Kerumut pada umumnya petani padi yang memiliki luas lahan pertanian yang beragam ada yang memiliki lahan diatas satu kektar dan sebagian besar memiliki lahan dibawah 0,50 ha, bahkan kurang dari 0,5 ha. Kenyataan ini membawa implikasi pada keragaman hasil pertanian yang diperoleh. Bagi yang memiliki lahan luas akan memperoleh hasil lebih banyak 
dibandingkan dengan yang memiliki lahan lebih sempit. Besar kecilnya hasil yang diperoleh akan menentukan wajib tidaknya membayar zakat hasil pertanian yang diperoleh.

Berdasarkan hal tersebut, maka kerangka pemecahan masalahnya adalah memberikan pemahaman tentang cara perhitungan dan penentuan besarnya zakat hasil pertanian dan bagaimana mendistribusikannya sesuai dengan syariat. Materi penyuluhan disusun dengan secara sederhana, mudah dimengerti dan menggunakan bahasa setempat yang dicampur dengan bahasa indonesia yang mudah dimengerti oleh khalayak sasaran pengabdian.

Kegiatan ini dilaksanakan di Desa Kerumut dengan memanfaatkan sarana Aula kantor desa sebagai tempat kegiatan pengabdian Masyarakat. Penyampaian materi digunakan metode ceramah dan diskusi kelompok terarah (Focud Group Discusion). Halayak sasaran penyuluhan adalah adalah para petani sebagai wajib zakat.

\section{HASIL DAN PEMBAHASAN}

\section{A. Zakat Hasil Pertanian}

Dalam pelaksanaan kegiatan pengabdian pada masyarakat ini, selain di dihadiri oleh para petani dan juga dihadiri dari unsur pemuka masyarakat, Tokoh agama dan para pengurus kelembagaan desa yang ada di Desa Kerumut, seperti Ketua dan anggota BPD, pengurus Bazda Desa Kerumut dan organisasi kepemudaan desa setempat. Dari diskusi dilakukan dengan para peserta yang hadir dalam pertemuan tersebut, diperoleh informasi bahwa para petani di Desa Kerumut telah menghitung dan mengeluarkan zakat hasil pertanian yang diperoleh segera setelah panen usai dilakukan.

Basarnya zakat hasil pertanian khususnya padi yang dikeluarkan oleh petani rata-rata sebesar 10 persen dari total hasil yang diperoleh. Besarnya zakat adi ditentukan berdasarkan kebiasaan petani setempat yang telah berlangsung sejak lama. Sesungguhnya besarnya zakat yang dikeluarkan oleh petani padi setempat lebih besar dari ketentuan besarnya zakat hasil pertanian padi yaitu sebesar 5 


\section{Jurnal ABDIMAS INDEPENDEN}

Vol. 2, No. 1, Mei 2021

persen, sebab lahan pertanian di desa Kerumut termasuk lahan pertanian tehnis dengan tiga kali musim tanam dalam satu tahun.

Zakat yang dikeluarkan oleh petani atas hasil pertanian padi yang diperoleh, diberikan secara langsung kepada yang berhak menerimanya yaitu orang-orang yang dianggap tergolong miskin oleh muzakki tersebut. Kendati di Desa Kerumut telah terbentuk atau berdiri lembaga Badan Amil Zakat Infak Sedekah (BAZIS), namun lembaga ini belum bekerja secara efektif dalam melayani kebutuhan ummat untuk membayar zakar dan atau menyalurkannya zakat tersebut kepada yang berhak menerimanya.

\section{B. Rencana Badan Amil Zakat Desa Berada Dibawah Ta'mir Masjid}

Badan Amil Zakat Infak Sedekah (Baziz) di Desa Kerumut belum bekerja secara efekti dalam memungut atau menerima zakat dari para muzakki. Hal ini merupakan kasus umum terjadi di berbagai Bazis yang ada banyak Desa. Hal ini disebabkan karena masyarakay masih belum percaya kepada lembaga Bazis sebagai pengelola zakat hasil pertanian petani maupun zakat lainnya. Selain itu juga para muzakki sebagian besar membayar zakat hasil pertaniannya langsung kepada orang yang dianggap berhak menerimanya, sehingga lembaga Bazis yang ada tidak di berdayakan secara efektif sebagai lembaga yang menyalurkan zakat tersebut kepada yang berhak menerimanya.

Pengelolaan Bazda ditingkat desa, sebaiknya berada di bawah ta'mir masjid, sebab pengelola masjid dapat dipercaya oleh masyarakat sebagai amil yang menerima, dan menyalurkan zakat kepada delapan asnap sesuai dengan ketentuan syariah. Penghimpunan zakat ini tidak terbatas untuk zakat pertanian saja tetapi meliputi jenis zakat lainnya seperti zakat harta, zakat ternak, zakat emas dan lainnya. Pengelolaan zakat melalui ta'mir masjid dapat diperluas dalam penyalurannya yaitu tidak saja untuk memenuhi kebutuhan pokok para mustahik tetapi dapat diperluas untuk biaya pendidikan bagi anak-anak yang kurang mampu, namum memiliki prestasi yang membanggakan. 


\section{SIMPULAN DAN SARAN}

Kesimpulan

Berdasarkan hasil diskusi atau tanya jawab yang dipaparkan dalam pembahasan di atas dapat ditarik kesimpulan sebagai berikut :

1. Petani padi di Desa Kerumut telah mengeluarkan zakat hasil pertanian sebesar 10 persen dari total hasil yang diperoleh tanpa melkukan pengurangan terhadap biaya produksi yang dikeluarkan.

2. Penyaluran zakat hasil pertanian dilakukan secara individual kepada anggota masyarakat yang dianggap berhak menerimanya.

3. Badan Amil Zakat yang ada di desa belum bekerja secara efektif karena para petani yang menyalurkan zakatnya tidak melalui lembaga Bazdes yang ada di Desa. Hal ini mungkin disebabkan oleh ketidakpercayaan para muzakki pada lembaga yang menghimpun dan menyalurkan zakat tersebut.

Saran

1. Pemberdayaan Ta'mir Masjid dalam menghimpun dan menyalurkan zakat dari para muzakki dimasa mendatang, karena dianggap lebih dipercaya untuk melaksanakan tugas keagamaan yang berfungsi sosial tersebut.

2. Para muzakki hendaknya menyalurkan zakat hasil pertanian maupun zakat yang lain melalui Ta'mis masjid.

\section{UCAPAN TERIMA KASIH}

Pelaksanaan kegiatan Pengabdian Kepada Masyarakat ini telah melibatkan berbagai pihak, oleh karena itu pada kesempatan ini kami mengucapkan terima kasih dan penghargaan kepada :

1 LPPM UNRAM selaku koordinator pelaksanaan pengabdian kepada masyarakat.

2 Fakultas Ekonomi dan Bisnis Universitas Mataram dan BP2EB Fakultas Ekonomi dan Bisnis Universitas Mataram.

3 Para petani Di Desa Kerumut Lombok Timur. 


\section{Jurnal ABDIMAS INDEPENDEN}

Vol. 2, No. 1, Mei 2021

\section{DAFTAR PUSTAKA}

2002. Perda Pengelolaan Zakat, Bagian Hukum Sekretariat Daerah. Lombok Timur.

2010. Laporan Pelaksanaan Kegiatan Tahun 2010, BAZDA, Lombok Timur.

2020. Kecamatan Pringgabaya Dalam Angka, Mataram

Muslim, Muslihun, 2005, Fiqih Ekonomi, LKIM UIN Mataram,

Muhasim, Ahmad, 2008, Pendidikan Agama Islam, Lembaga Cerdas Press, Mataram.

Rasjid, H. Sulaiman, 1989, Fiqh Islam, Sinar Baru, Bandung.

Indrijatiningrum, Mustikorini, 2005, Zakat Sebagai Alternatif Penggalangan Dana Masyarakat Untuk Pembangunan, EKSIS, Jakarta.

Nurlaili, 2008, Prospek Zakat Sebagai Salah Satu Pembentuk PAD di Kabupaten Lombok Timur, Skripsi, Tidak dipublikasikan.

Khatimah, Husnul, 2005, Pengaruh Zakat Produktif Terhadap Peningkatan Kesejahteraan Ekonomi Para Mustahik, EKSIS, Jakarta

Yasin, Muaidy, 2011. Pembiayaan Usaha Tani dan Implikasinya pada Pendapatan dan Kesejahteraan Petani Padi Dalam Perspektif Islam di Lombok Tumur. Disertasi. 